\title{
The Impact of Human Parvovirus B19 Co-Infection on Liver Function of HCV Infected Patients
}

\author{
Mohamed Nabil1,2*, Mohammed H. Saiem Al-Dahr¹, Waleed Abu Al-Soud1', Omar Alfaruok² \\ ${ }^{1}$ Department of Clinical Laboratories, College of Applied Medical Sciences, Jouf University, Al-Qurayyat, KSA \\ ${ }^{2}$ Department of Microbiology, Faculty of Science, Ain Shams University, Cairo, Egypt \\ Email: *mnmicro2010@gmail.com
}

How to cite this paper: Nabil, M., AlDahr, M.H.S., Al-Soud, W.A. and Alfaruok, O. (2019) The Impact of Human Parvovirus B19 Co-Infection on Liver Function of HCV Infected Patients. Open Journal of Applied Sciences, 9, 17-25.

https://doi.org/10.4236/ojapps.2019.91003

Received: January 4, 2019

Accepted: January 25, 2019

Published: January 28, 2019

Copyright () 2019 by author(s) and Scientific Research Publishing Inc. This work is licensed under the Creative Commons Attribution International License (CC BY 4.0).

http://creativecommons.org/licenses/by/4.0/

(c) (i) Open Access

\begin{abstract}
Background: Human Parvovirus B19 is most known for causing disease in the pediatric population but can also affect adults. Human co-infection with Parvovirus B19 could deteriorate the prognosis of patient with chronic illness. Objectives: This paper attempts to determine the prevalence of Parvovirus B19 in HCV infected patients and to evaluate the impact of Parvovirus B19 on liver enzymes activity of Hepatitis C patients. Study Design: The study population includes 74 chronic HCV (patient group) and 49 cases without viral hepatitis (control group). Nucleic acid of Parvovirus B19 was detected in Serum samples by nested polymerase chain reaction (nested-PCR) method. Results: Parvovirus B19-DNA infection was detected in $28.0 \%$ of chronic HCV patients. Parvovirus B19-HCV co-infection caused increasing in Alanine aminotransferase (ALT) and Aspartate aminotransferase (AST) activity than in B19-negative HCV patients. Conclusion: We conclude that Parvovirus B19 acted synergistically with HCV by increasing the levels alanine aminotransferase (ALT) and Aspartate aminotransferase (AST).
\end{abstract}

\section{Keywords}

Parvovirus B19, HCV, Co-Infection, ALT and AST

\section{Introduction}

Human Parvovirus B19 infection may lead to a wide spectrum of clinical manifestations including a mild childhood rash (erythema infectiosum), but this virus can also cause several other diseases, transient aplastic crisis in patients with haemolytic anaemia, and congenital hydrops foetalis, meningoencephalitis, 
hepatitis and chronic infection in immunocompromised patients (Ornoy et al., 2017; Broliden et al., 2006) [1] [2]. Parvovirus B19 is a member of the erythrovirus genus of Parvoviridae family. It infects more than $50 \%$ of the adult population all over the world (Adler et al., 2006) [3]. The different diseases of Parvovirus B19 represent direct consequences of its ability to target the erythroid cell lineage (Kumar et al., 2013) [4]. The role of Parvovirus B19 in the evolution of chronic hepatitis from hepatotropic viruses is considered. Chronic Parvovirus B19 associated hepatitis is suspected in immunocompetent adults with compatible serology, suggestive histology and detection of the viral genome in the liver and/or increase of specific circulating cytotoxic T-lymphocytes (Mogensen et al., 2010) [5]. The exact association of parvovirus B19 co-infection in CHC infected patients directly correlates with the probability of progression to more severe fibrosis, cirrhosis and hepatocellular carcinoma (Opaleye et al., 2011) [6].

\section{Objective}

The present study aimed to investigate the incidence of co-infection of Human Parvovirus B19 in sera samples from patients (cases with positive HCV infection) and controls (cases with negative HCV infection). It aimed to study the effect of B19 pathogenicity on the changes in the liver functions (like liver enzymatic activity of ALT and AST).

\section{Material and Methods}

\subsection{Study Population}

This study (approved by the Ethical Committee of Ain Shams University) consisted of a patient group $(n=74)$ with chronic viral hepatitis $C$ and a control group $(n=49)$ without viral hepatitis, all samples were collected from Cairo (Sayed Galal hospital), Sohaj (Sohaj general hospital) and Mansoura (Mansoura University hospital). We evaluated 74 consecutive patients with chronic hepatitis C (mean age $42.5 \pm 10.2$ years; range: $19-65 ; 41$ males, 33 females). All of the chronic HCV patients were positive for antibodies against hepatitis $\mathrm{C}$ virus (anti-HCV) and serum HCV-RNA. The control group ( $n=49$; mean age $30.25 \pm$ 7.5 range: 17 - 54; 31 males, 18 females) consisted of individuals without viral hepatitis. All of the control patients were negative for anti-HCV and HCV-RNA. The age, sex, alanine aminotransferase (ALT) levels, antibodies against Parvovirus B19 (anti-B19-IgM, anti-B19 IgG), B19-DNA of the serum samples of the cases were assessed and recorded.

\subsection{Serological Analysis of Parvovirus B19 Infection}

B19-IgM and B19-IgG antibodies were determined by the enzyme-linked immunosorbent assay (ELISA) technique using commercially available B19-IgM and IgG Kits. B19-IgM antibodies were determined by commercially available Diagnostic Automation B19-IgM Kit (Diagnostic Automation, INC 23961 Craftsman Road, Suite D/E/F, Calabasas, CA 91302, USA). B19-IgG antibodies were 
determined by commercially available ATLAS Medical, William James House, Cowley Road, Cambridge, CB4 OWX, UK. Tests were done according to the instructions of the manufacturer.

\subsection{Detection of HCV RNA}

RNA was isolated from serum samples as described by Lohr et al., (1995) and El Awady et al., (2006) [7] [8]. Reverse transcription-nested PCR was carried out according to Chomczynski and Sacchi (1992) [9]. Primers used for detecting HCV in clinical samples were purchased from Promega and their sequences were as following: P1: 5'GGTGCACGGTCTACGAGACCTC 3'-P2:

5'AACTACTGTCTTCACGCAGAA 3'-P3: 5' TGCTCATGGTGCACG GTCTA 3'-P4: 5' ACTCGGCTAGCAGTCTCGCG 3'-P5: 5'

GTGCAGCCTCCAGGACCC 3' (Madison, WI, USA).

\subsection{Detection of B19-DNA}

Viral nucleic acid DNA was extracted from serum sample using Wizard ${ }^{\circledR}$ DNA purification mini kit, Promega (Madison, USA). Nested PCR of serum samples for detection of B19-DNA was carried according to Pinho et al., (2001) [10]. The reaction mixture of the qualitative PCR contained, in total volume of $25 \mu \mathrm{l}, 0.5 \mathrm{ul}$ of $2 \mathrm{Mm}$ dNTPs mix, $0.75 \mathrm{ul}$ of $25 \mathrm{Mm} \mathrm{MgC12,} 0.25 \mathrm{ul} 2.5 \mathrm{U}$ Taq DNA polymerase, $2.5 \mathrm{ul} 5 \mathrm{X}$ buffer and $14 \mathrm{ul} \mathrm{DW}$. 5ul of DNA mixed with $2 \mathrm{ul}(10 \mathrm{pmol})$ of each primer. Outer primers: forward p1 (5' AAT ACA CTG TGG TTT TAT GGG CCG 3') and reverse p6 (5’ CCA TTG CTG GTT ATA ACC ACA GGT 3'). The second round of the nested PCR was done by 2 ul PCR product of the first round using 10 pmol of each primers Inner primers; forward p2 (5' CCA TTG CTG GTT ATA ACC ACA GGT 3') and reverse p5 (5' CTA AAA ATG GCT TTT GCA GCT TCT AC 3') (Bioneer, Atlantic Avenue, Alameda, USA) for amplification of $185 \mathrm{bp}$.

\subsection{Agarose Gel Electrophoresis and Analysis of Nested-PCR Product}

Analysis of nested-PCR products were performed according to Aaij and Borst, (1972) [11]. Amplification products of both HCV RT-nested PCR and B19 nested-PCR were visualized after electrophoresis on $2 \%$ agarose gel stained with ethidium bromide.

\subsection{Biochemical Analysis}

Biochemical tests, including Alanine amino transferase (normal range, $40 \mathrm{U} / \mathrm{L}$ ) and Aspartate amino transferase (normal range, $38 \mathrm{U} / \mathrm{L}$ ) levels were done on all collected samples with commercially available Flex ALAT (GPT) and ASAT (GOT) Kits (Siemens Healthcare Diagnostic Inc., USA). Tests were done according to the instructions of the manufacturer.

\subsection{Statistical Analysis}

All statistical analyses were performed using SPSS statistical software program. 
Differences were considered significant when $\mathrm{p} \leq 0.05$.

\section{Results}

\subsection{Detection of Anti-B19 Antibodies in Study and Control Groups}

From the study group, 42 out of $74(56.7 \%)$ chronic HCV were positive for B19-IgG antibodies (Table 1). Sera from 17 out of 49 (34.7\%) individuals from the control group were positive for B19-IgG antibodies (Table 2).

Five patients out of $74(6.7 \%)$ chronic HCV were positive for B19-IgM antibodies (Table 1). Three cases out of 49 (6.1\%) from the control group was positive for B19-IgM antibodies (Table 2).

\subsection{Detection of B19-DNA by Nested PCR}

In chronic HCV patients, B19-DNA was positive in $28 \%$ (21/74) of the serum samples. B19-DNA was detected in 7 out of 49 (14.3\%) samples obtained from the control group. The difference between the presence of B19-DNA in patients with chronic HCV infection and the control group was statistically significant (p $<0.01$ ) (Figure 1).

\subsection{Serum Levels of the Liver Transaminases in the Study Groups}

In positive $\mathrm{HCV}$-RNA patient group, serum ALT activity levels was detected as $81.89 \pm 16.2 \mathrm{IU} / \mathrm{L}$ which means that, it was higher than that of control group $32.98 \pm 12.7 \mathrm{IU} / \mathrm{L}$. Also serum AST activity level of HCV patient group was 80.18 $\pm 15.8 \mathrm{IU} / \mathrm{L}$ and higher than that of control group $31.7 \pm 12.46 \mathrm{IU} / \mathrm{L}$ (Figure 2).

- In HCV-positive group (patient group), serum ALT levels (mean: $94.41 \pm$ $9.81 \mathrm{U} / \mathrm{l})$ in B19-positive patients were slightly higher than that of B19-negative patients (mean: $73.53 \pm 13.74 \mathrm{IU} / \mathrm{l}$ ). Serum AST activity level of B19-positive patients (mean: $91.4 \pm 9.3 \mathrm{IU} / \mathrm{L}$ ) was also slightly higher than that of B19negative patients (mean: $71.6 \pm 12.41 \mathrm{IU} / \mathrm{L}$ ) (Figure 3).

- In Control group, serum ALT levels (mean: $42.3 \pm 3.1 \mathrm{U} / \mathrm{l}$ ) in B19 -positive patients were slightly higher than that of B19-negative patients (mean: $30.4 \pm$ $10.75 \mathrm{U} / \mathrm{l}$ ). Serum AST activity level of B19-positive patients (mean: $41.47 \pm$ $2.4 \mathrm{IU} / \mathrm{L}$ ) was also slightly higher than that of B19-negative patients (mean: $31.2 \pm 11.71 \mathrm{IU} / \mathrm{L}$ ) (Figure 4 ).

Table 1. Detection of B19-IgG and IgM antibodies among patient group.

\begin{tabular}{ccccccccccc}
\hline & \multicolumn{3}{c}{ Positive B19-IgG samples } & \multicolumn{3}{c}{ Positive B19-IgM samples } \\
\hline \multirow{3}{*}{ Sex } & \multicolumn{3}{c}{ Male } & \multicolumn{2}{c}{ Female } & \multicolumn{2}{c}{ Male } & \multicolumn{2}{c}{ Female } \\
\cline { 2 - 9 } & No. & $\%$ & No. & $\%$ & No. & $\%$ & No. & $\%$ \\
\cline { 2 - 9 } Total & & & 40.8 & 25 & 59.2 & 4 & 66.7 & 1 & 33.3 \\
\hline
\end{tabular}


Table 2. Detection of B19-IgG and IgM in Control group.

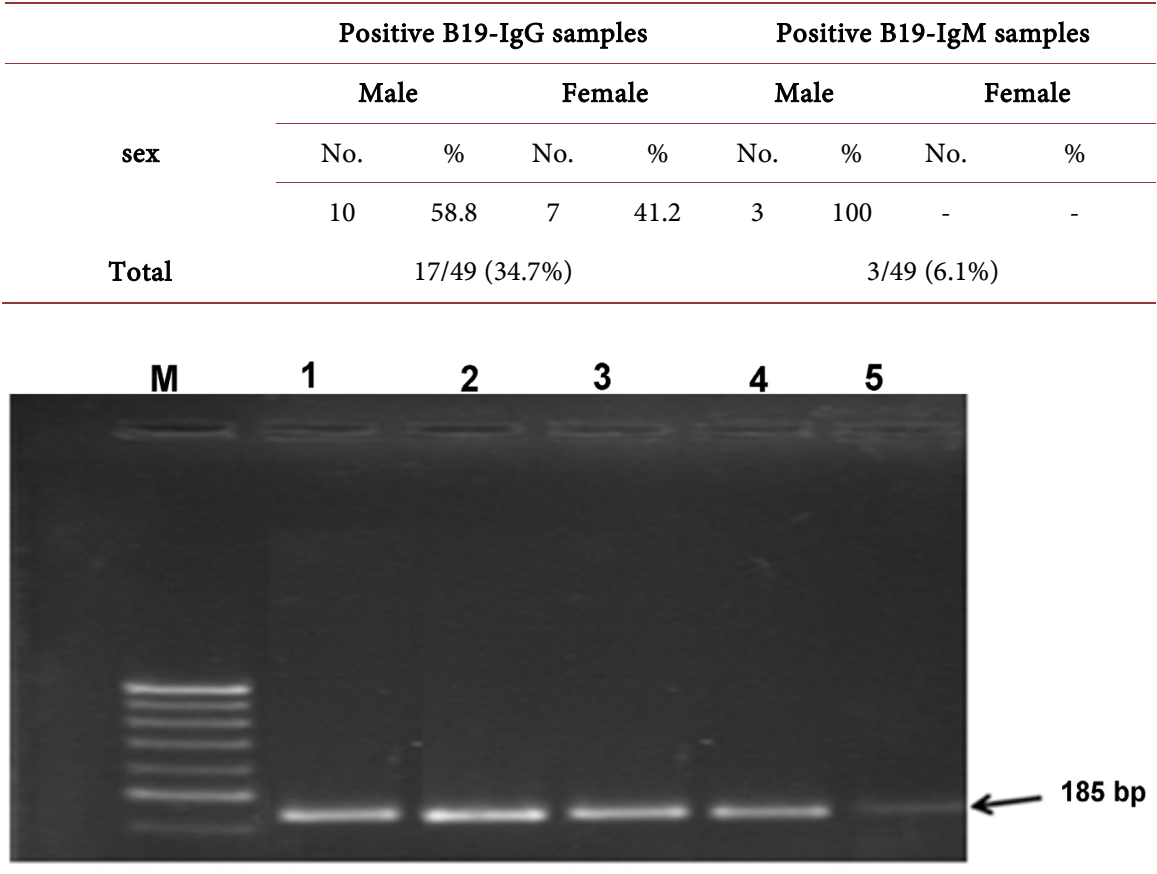

Figure 1. Results of Nested PCR of Parvovirus B19 DNA in serum samples. Lanes 1, 2, 3, 4 positive for B19 virus; 5 negative for B19 DNA.

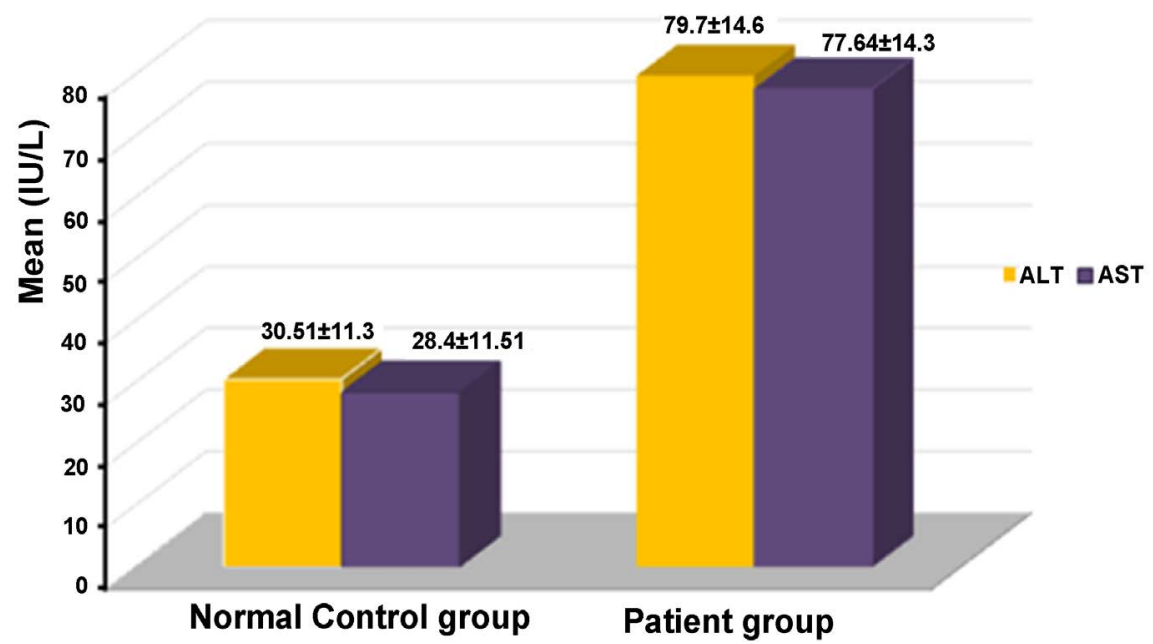

Figure 2. The activity level of ALT and AST liver enzymes in patients and control groups.

\section{Discussion}

Human Parvovirus B19 infection is considered a serious disease, because it causes complications especially among immune suppressed patients (Tolfvenstam et al., 2009) [12]. Parvovirus B19 associated with Liver dysfunctions have been reported by several authors, especially involving acute hepatitis cases (Pinho et al., 2001 and Wang et al., 2009) [10] [13], Virus-virus interactions have been demonstrated to modify the pathogenesis of human viral infections (Palma et al., 2010) [14]. 


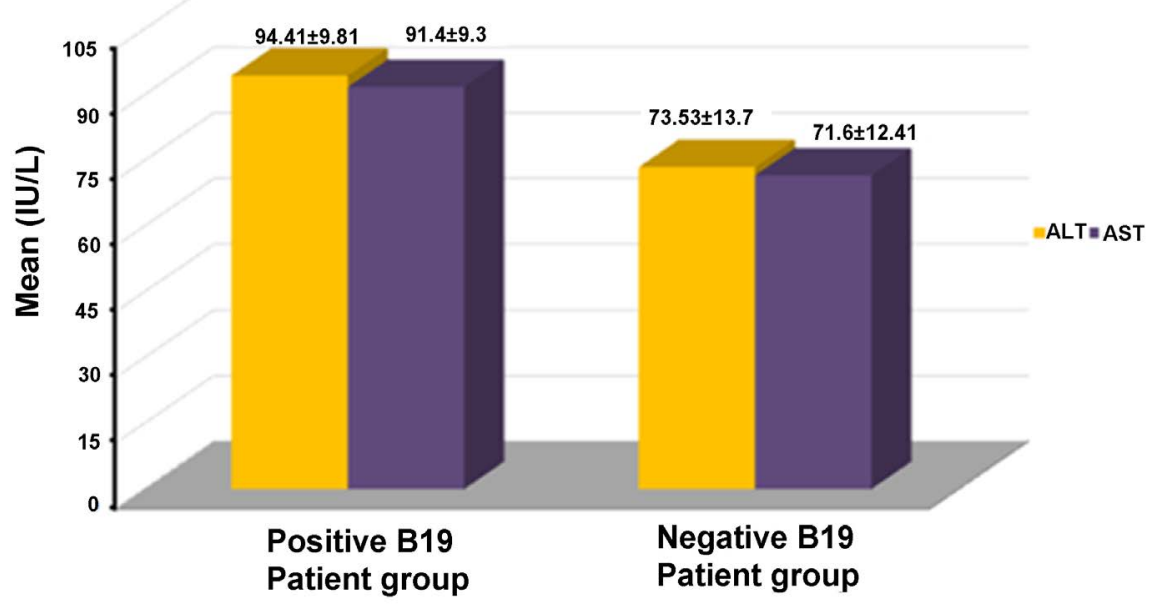

Figure 3. The activity level of ALT and AST liver enzymes in B19-patient group.

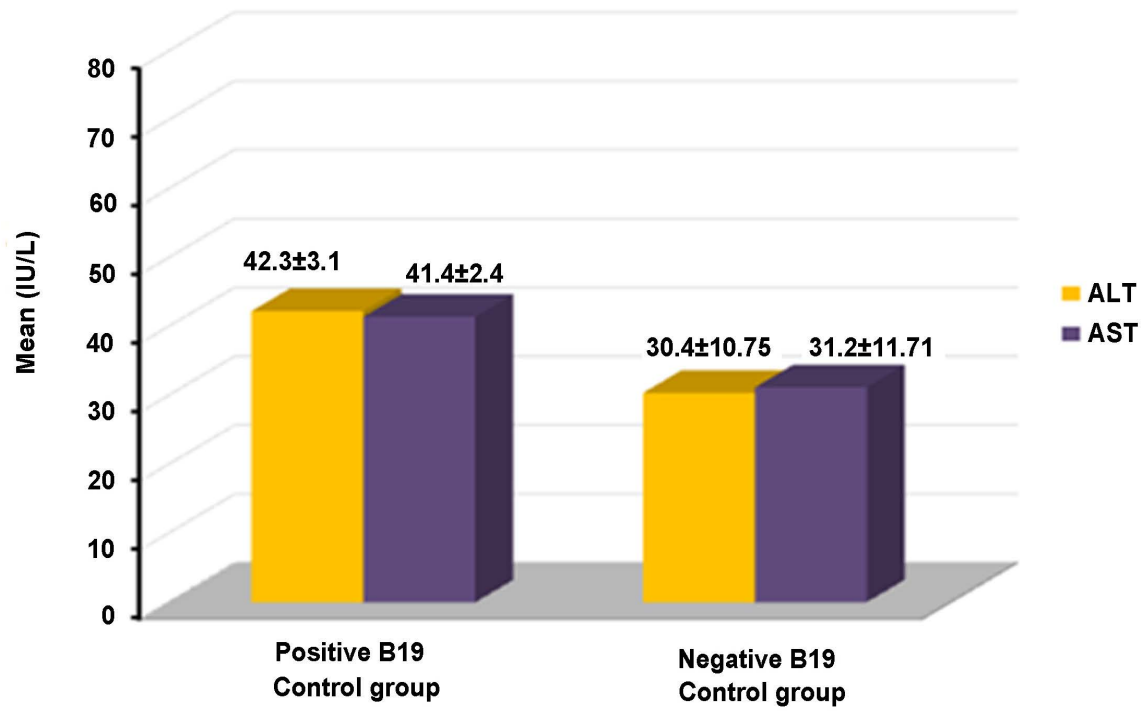

Figure 4. The activity level of ALT and AST liver enzymes in B19-Control group.

In this study, we investigated the incidence of B19 infection in Egyptian HCV patients who progressed to chronic HCV infection and we examined the potential role that B19 virus plays in HCV progression. The data of this study showed that the percentage of positive B19-Abs were significantly higher $(\mathrm{p}<0.001)$ in chronic HCV patient than those in Control group. Also, the B19-DNA was detected in $28.0 \%$ of chronic HCV infected patients compared with 7 out of 49 (14.3\%) Control group cases. The previous results are in complete accordance with those of other studies which emphasize the presence of human parvovirus B19 infection in 129 patients with HCV (Pinho et al., 2001) [10]. The difference between the presence of B19 DNA among patients and the control group was statistically significant $(\mathrm{p}<0.05)$. Moreover, the results proved that the detection of B19 DNA by PCR in peripheral blood leukocytes is a sensitive and reproducible procedure for detecting viral infection. Serological methods have been re- 
ported to be insensitive and can't distinguish between B19 infection and B19 disease as IgM antibodies may persist for months or years and may be detected during reactivation of latent virus infections (Brown et al., 2015) [15].

In the two study groups (Patient group and Control), we study the activity levels of ALT and AST liver enzymes. In HCV-RNA positive cases, serum activity levels of ALT and AST enzymes illustrated in this study showed a highly significant $(\mathrm{p}<0.001)$ elevation in positive B19-DNA than negative individuals. These findings indicated that active B19 infection in chronic HCV patients had high influence on activity of ALT and AST enzymes by increasing their levels in sera of Parvovirus B19 patients. These data showed that primary and reactivated Parvovirus B19 infections in chronic HCV patients had high effect on liver enzymes, which seems to be attributed to the immune system of the chronic HCV patient. This result was in agreement with the report of Verma et al., (2016) [16], who showed that Parvovirus B19 causes elevation of transaminases, acute hepatitis, fulminant liver failure and chronic hepatitis.

There was high effect of B-19 parvovirus infection on the serum activity levels of ALT and AST in HCV patients and immunosuppressed individuals. These findings are revealed in other studies as DNA of parvovirus B-19 and other viruses are more frequently encountered in specimens from patients with $\mathrm{HCV}$ hepatitis than from subjects without liver hepatitis (Toan et al., 2006; Mogensen et al., 2010) [5] [17]. Parvovirus B19 induces liver pathology and failure through programmed cell death of hepatocytes by action of viral protein nonstructural protein-1 (NS1) and mediated through an intrinsic caspase pathway, involving caspases 3 and 9 (Liu et al., 1992; Poole et al., 2006) [18] [19].

In HCV negative group (Control group), ALT and AST activity levels in positive B19-DNA cases were slightly higher than that in negative cases. All the previous results indicated that the pathogenesis of HCV is influenced by its interaction with B19 virus. These data are in agreement with other studies donated that, B19 virus infection can cause liver function test abnormalities (Mogensen et al., 2010) [5]. Liver involvement usually causes mild elevation of transaminases and this abnormality resolves spontaneously (Bihari et al., 2013) [20].

The results of this study showed that infection with parvovirus B19 was prevalent in HCV patients (Bernuau et al., 1999 and Hsu et al., 2005) [21] [22]. B19 viruses may exert an immunomodulatory effect resulting in enhanced immunosuppression (Shan et al., 2001) [23].

The results of this study is in agreement with other studies (Krygier et al., 2009; Petrova et al., 2010) [24] [25] who reported that, in some patients with chronic liver disease caused by a major hepatotropic virus, an infection with other viral agents may be discovered. We previously evaluated patients with chronic hepatitis B and C regarding their parvovirus B19 serology. Opaleye et al. (2011) [6] reported that, the patients with reactivated B19 infection had lower levels of HBV DNA and higher mean values of serum hepatitis C virus (HCV) RNA as compared to parvovirus B19 -seropositive patients without reactivation. 


\section{Conclusion}

We recommend introducing Parvovirus B19 treatment in HCV patients to prevent rapid deterioration and to slow the progression to liver fulminant liver failure and chronic hepatitis.

\section{Conflicts of Interest}

The authors declare no conflicts of interest regarding the publication of this paper.

\section{References}

[1] Ornoy, A. and Ergaz, Z. (2017) Parvovirus B19 Infection during Pregnancy and Risks to the Fetus. Birth Defects Research, 109, 311-323. https://doi.org/10.1002/bdra.23588

[2] Broliden, K., Tolfvenstam, T. and Norbeck, O. (2006) Clinical Aspects of Parvovirus B19 Infection. Journal of Internal Medicine, 260, 285-304. https://doi.org/10.1111/j.1365-2796.2006.01697.x

[3] Adler, S.P. and Koch, W.C. (2006) Human Parvovirus Infections. In: Remington, J.S., Klein, J.O., Wilson, C.B. and Baker, C.J., Eds., Infectious Diseases of the Fetus and Newborn Infant, 6th Edition, Saunders Elsevier, Philadelphia, 868-892.

[4] Kumar, S., Gupta, R.M., Sen, S., et al. (2013) Seroprevalence of Human Parvovirus B19 in Healthy Blood Donors. Medical Journal Armed Forces India, 69, 268-272. https://doi.org/10.1016/j.mjafi.2012.11.009

[5] Mogensen, T.H., Jensen, J.M., Hamilton-Dutoit, S. and Larsen, C.S. (2010) Chronic Hepatitis Caused by Persistent Parvovirus B19 Infection. BMC Infectious Diseases, 10, 246. https://doi.org/10.1186/1471-2334-10-246

[6] Opaleye, O.O., Fagbami, A.H., Lalremruata, A. and Kun, J.F. (2011) Prevalence and Association of Human Parvovirus B19V with Hepatitis B and C Viruses in Nigeria. Journal of Medical Virology, 83, 710-716. https://doi.org/10.1002/jmv.22008

[7] Lohr, H.F., Goergen, B., Meyerzum, K.H. and Gerken, G. (1995) HCV Replication in Mononuclear Cells Stimulates Anti-HCV Secreting B Cells and Reflects Nonresponsiveness to Interferonalpha. Journal of Medical Virology, 46, 314-320. https://doi.org/10.1002/jmv.1890460405

[8] El Awady, M., Tabll, A., El-Abd, Y., Bahgat, M., Shoeb, H., Youssef, S., Bader El Din, N., Redwan, M., El-Demellawy, M., Omran, M., El-Garf, W. and Goueli, S. (2006) HepG2 Cells Support Viral Replication and Gene Expression of Hepatitis C Virus Genotype 4 in Vitro. World Journal of Gastroenterology, 14, 4836-4842.

[9] Chomczynski, P. and Sacchi, N. (1992) Single-Step Method of RNA Isolation by Acid Guanidium-Thiocyanatephenol-Chloroform Extraction. Analytical Biochemistry, 162, 156-159. https://doi.org/10.1016/0003-2697(87)90021-2

[10] Pinho, J.R., Alves, V.A., Vieira, A.F., Moralez, M.O., Fonseca, L.E., Guz, B., et al. (2001) Detection of Human Parvovirus B19 in a Patient with Hepatitis. Brazilian Journal of Medical and Biological Research, 34, 1131-1138. https://doi.org/10.1590/S0100-879X2001000900005

[11] Aaij, C. and Borst, P. (1972) The Gel Electrophoresis of DNA. Biochimica et Biophysica Acta, 269, 192. https://doi.org/10.1016/0005-2787(72)90426-1

[12] Tolfvenstam, T. and Broliden, K. (2009) Parvovirus B19 Infection. Seminars in Fetal and Neonatal Medicine, 14, 218-221. https://doi.org/10.1016/j.siny.2009.01.007 
[13] Wang, C., Heim, A., Schlaphoff, V., Suneetha, P.V., Stegmann, K.A. and Jiang, H. (2009) Intrahepatic Longterm Persistence of Parvovirus B19 and Its Role in Chronic Viral Hepatitis. Journal of Medical Virology, 81, 2079-2088. https://doi.org/10.1002/jmv.21638

[14] Palma, T.Da., Doonan, B.P., Trager, N.N.M. and Kasman, L.M. (2010) A Systematic Approach to Virus-Virus Interactions. Virus Research. https://doi.org/10.1016/j.virusres.2010.01.002

[15] Brown, K.E., Bennet, J.E., Dolin, R. and Blaser, M. (2015) Parvovirus B19. Mandell, Douglas and Bennett's Principals and Practice of Infectious Diseases, 8th Edition, Churchill Livingstone Elsevier, Philadelphia, Vol. 2, 1840-1847.

[16] Verma, Y., Gupta, E., Reddy, H.V., Ballani, N., Bajpai, M. and Bhadoria, A.S. (2016) Human Parvovirus B19 Co-Infection Aggravates Liver Dysfunction in Patients with Chronic Hepatitis B Infection. J Gastrointest Infect, 6, 32-36.

[17] Toan, N.L., Song, L.H., Kremsner, P.G., Duy, D.N., Binh, V.Q., Duechting, A., et al. (2006) Co-Infection of Human Parvovirus B19 in Vietnamese Patients with Hepatitis B Virus Infection. Journal of Hepatology, 45, 361-369. https://doi.org/10.1016/j.jhep.2006.03.013

[18] Liu, J.M., Green, S.W., Shimada, T. and Young, N.S. (1992) A Block in Full-Length Transcript Maturation in Cells Nonpermissive for B19 Parvovirus. Journal of $\mathrm{Vi}$ rology, 66, 4686-4692.

[19] Poole, B.D., Zhou, J., Grote, A., Schiffenbauer, A. and Naides, S.J. (2006) Apoptosis of Liverderived Cells Induced by Parvovirus B19 Nonstructural Protein. Journal of Virology, 80, 4114-4121. https://doi.org/10.1128/JVI.80.8.4114-4121.2006

[20] Bilhari, C., Rastogi, A., Saxena, P., Rangegowda, D., et al. (2013) Parvovirus B19 Associated Hepatitis. Hepatitis Research and Treatment, 2013, Article ID: 472027. https://doi.org/10.1155/2013/472027

[21] Bernuau, J., Durand, F. and Valla, D. (1999) Parvovirus B19 Infection and Fulminant Hepatitis. The Lancet, 353, 754-755. https://doi.org/10.1016/S0140-6736(05)76124-9

[22] Hsu, T.C., Chen, T.Y., Lin, M.C., Tzang, B.S. and Tsay, G.J. (2005) Human Parvovirus B19 Infection in Patients with Chronic Hepatitis B or Hepatitis C Infection. Journal of Gastroenterology and Hepatology, 20, 733-738. https://doi.org/10.1111/j.1440-1746.2005.03815.x

[23] Shan, Y.S., Lee, P.C., Wang, J.R., Tsai, H.P., Sung, C.M. and Jin, Y.T. (2001) Fibrosing Cholestatic Hepatitis Possibly Related to Persistent Parvovirus B19 Infection in a Renal Transplant Recipient. Nephrology Dialysis Transplantation, 16, 2420-2422. https://doi.org/10.1093/ndt/16.12.2420

[24] Krygier, S., Steinbrecher, U.P., Petric, M., Erb, S.R., Chung, S.W. and Scudamore, C.H. (2009) Parvovirus B19 Induced Hepatic Failure in an Adult Requiring Liver Transplantation. World Journal of Gastroenterology, 15, 4067-4069. https://doi.org/10.3748/wjg.15.4067

[25] Petrova, M. and Kamburov, V. (2010) Epstein-Barr Virus: Silent Companion or Causative Agent of Chronic Liver Disease? World Journal of Gastroenterology, 16, 4130-4134. https://doi.org/10.3748/wjg.v16.i33.4130 